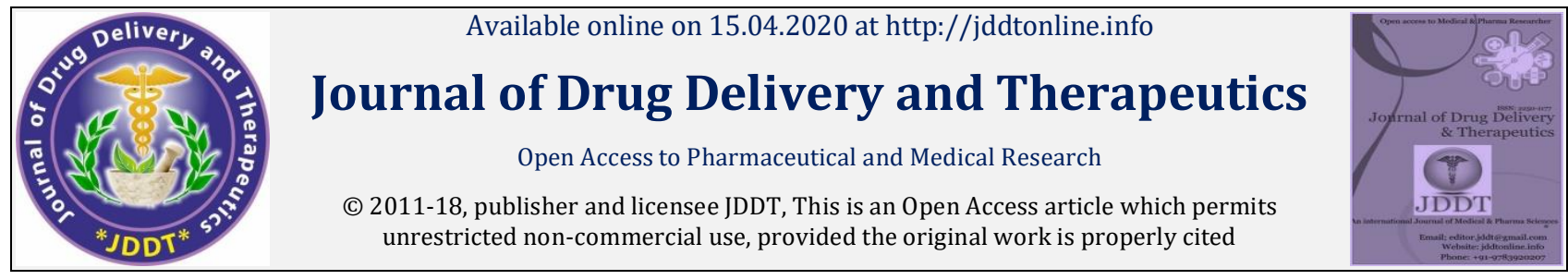

Open 2 Access

Research Article

\title{
Chemical composition, antibacterial activity of essential oil and anatomical study of Chrysanthemum morifolium
}

\author{
Boukhebti H. ${ }^{1}$, Demirtas I. ${ }^{2}$, Omar L. ${ }^{3}$, Chaker A.N. ${ }^{1}$ \\ 1 Laboratory of Natural Resource Valorization. Faculty of Nature Life Sciences. Ferhat Abbas University Setif-1.19000, Setif. Algeria \\ 2 Department of Chemistry. Faculty of Natural Sciences. Cankiri Karatekin University. 18200. Cankiri. Turkey \\ 3 Department of Ecology and Vegetal Biology . Faculty of Nature and Life Sciences. Ferhat Abbas University Setif-1.,19000 Setif. Algeria
}

\begin{abstract}
The aim of this study is to identify the chemical composition and to evaluate the antimicrobial activity of Chrysanthemum morifolium. The analysis and identification of essential oil which obtained by hydrodistilation method were realized by gaz chromatography and mass spectroscopy. The antibacterial activity was tested by using the agar diffusion test and the Gram positive and negative pathogenic bacteria: Staphylococcus aureus ATCC 25923. Escherichia coli ATCC 25922, Pseudomonas aeruginosa ATCC 27853 and Citrobacter freundii ATCC 8090, Kleibseilla pneumoniae ATCC 700603 and Shigella sonnei were used to evaluate this activity. This analysis led to the identification of 26 compounds representing $88.40 \%$ of the total essential oil mass. The major compound was Verbenone (17.33 \%). Other components present in appreciable contents were: Chrysanthenone (9.71\%). 4-epi-cubedol (07.25\%) and $\delta$-Cadinol (05.29 \%). Essential oil of Chrysanthemum morifolium exhibited an antibacterial effect against pathogenic bacteria, like those observed against Staphylococcus aureus ATCC 25923 (35 $\pm 1.2 \mathrm{~mm}$ ) and Citrobacter freundii ATCC 8090 (21 $\pm 0.87 \mathrm{~mm}$ ), however Pseudomonas aeruginosa ATCC 27853 and Kleibseilla pneumoniae ATCC 700603 were resistant. The anatomical study showed the presence of several types of trichomes including the glands secreted for essential oils and protector trichomes.
\end{abstract}

Keywords: essential oil, antibacterial activity, Chrysanthemum morifolium, anatomical study, chemical composition

Article Info: Received 29 Jan 2020; $\quad$ Review Completed 12 March 2020; $\quad$ Accepted 19 March 2020; Available online 15 April 2020

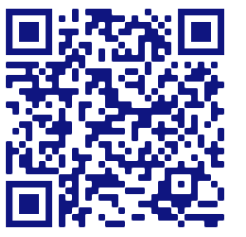

Cite this article as:

Boukhebti H, Demirtas I, Omar L, Chaker AN, Chemical composition, antibacterial activity of essential oil and anatomical study of Chrysanthemum morifolium, Journal of Drug Delivery and Therapeutics. 2020; 10(2-s):7-13 http://dx.doi.org/10.22270/jddt.v10i2-s.4015

Boukhebti H., Laboratory of Natural Resource Valorization. Faculty of Nature Life Sciences. Ferhat Abbas University Setif-1.19000, Setif. Algeria

\section{INTRODUCTION}

The genus Chrysanthemum belongs to the Asteraceae family and consists of 300 species [01]. The Chrysanthemum is one of the most popular traditional used species and one of the most popular cut flowers in the world [02].

Chrysanthemum morifolium is well known not only as an ornamental plant, but also as an important medicinal plant and a major source of natural products (flavonoids, sesquiterpene lactones, essential oils, triterpene diols and triols) used as pharmaceutical ingredients because this plant possess antibacterial, antifungal, antiviral and antispirochetal as has been reported in many studies [03], several studies show that the extracts of $C$. morifolium have antioxidant, cardiovascular protective, antiinflammatory functions and potent neuroprotective activity and therefore, might be a potential candidate in neurodegenerative diseases such as Parkinson's disease. It therefore occupies a very important position in the world flower industry. The flowers of $C$. morifolium have been used in Vietnam and other Asian countries for the treatment of eye diseases, headaches, insomnia and hyperglycemia [02]. In Algeria the genus includes 20 species with 8 endemic [04]. Chrysanthemum has been investigated for its biological activities and chemical compositions.

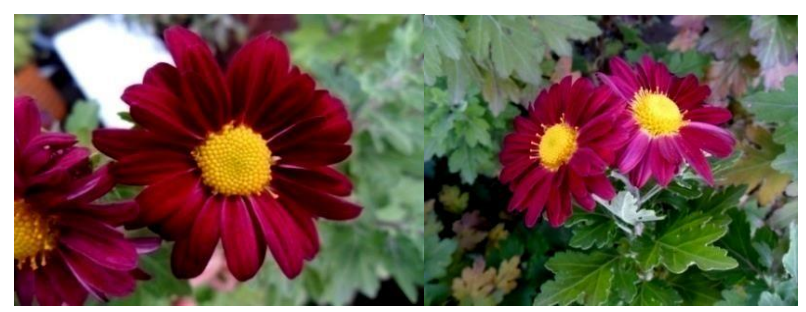

Fig. 01: Chrysanthemum morifolium 


\section{MATERIALS AND METHODS}

\section{Plant materiel}

Aerial parts of Chrysanthemum morifolium were harvested during June 2015 from the North of wilaya of Sétif (north east Algeria), then plant parts were washed with tap water to eliminate soil and other surface contaminants, after the dryness at laboratory temperature and obscurity. The plant material was cut to small pieces with universal knife.

\section{Extraction of the essential oil}

The air-dried aerial parts of $C$. morifolium were subjected to hydrodistillation for $3 \mathrm{~h}$ with distilled water using a Clevenger-type apparatus [05]. The oil obtained was collected and dried over anhydrous sodium sulfate and stored in screw capped glass vials in a refrigerator at $4-5^{\circ} \mathrm{C}$ prior to analysis. Yield based on dried weight of the samples was calculated.

\section{GC and GC-MS analysis}

GC analyses were carried out on a Perkin-Elmer Clarus 500 Series. in split mode. 50:1. Equipped with a flame ionization detector (FID) and a mass spectrometerequipped BPX-5 a polar capillary column $(30 \mathrm{~m} \times 0.25$ $\mathrm{mm}$. $0.25 \mathrm{~m}$ i.d.). The injection temperature was fixed and FID was executed at $250 \stackrel{\circ}{\circ} \mathrm{C}$. The carrier gas was helium at a rate of $1.0 \mathrm{~mL} / \mathrm{min}$. The initial column oven temperature was

$50{ }^{\circ} \mathrm{C}$ and was raised to $220{ }^{\circ} \mathrm{C}$ at a rate of 8 ${ }^{\circ} \mathrm{C} /$ minute. In the mass spectrometer transfer line temperature was at $250{ }^{\circ} \mathrm{C}$, ionization energy was 70 $\mathrm{eV}$. Analytical standards were used for the identification of components and Kovats retention indices (RIs) were determined for all the sample components using the Van den Dool and Kratz equation according to the retention times of homologous series of n-alkane [06].

\section{Antibacterial activity}

Two Gram positive and four Gram negative bacterial species were used in present study:

- Staphylococcus aureus ATCC25923

- Pseudomonas aeruginosa ATCC27853
- Escherichia coli ATCC 25922

- Citrobacter freundii ATCC 8090

- Kleibseilla pneumoniae ATCC 700603

- Shigella sonnei

The antibacterial activity of oil samples were evaluated by disc diffusion assay [07]. The bacterial inoculums were prepared (OD: 0.08-01 at $625 \mathrm{~nm}$ ). MullerHinton agar ( $\mathrm{MH}$ agar) was poured in Petri dishes solidified and surface dried before inoculation. Sterile discs ( $6 \mathrm{~mm} \Phi)$ were placed on inoculated agars, by test bacteria filled with $10 \mu \mathrm{l}$ of mother solution and diluted essential oil (1:2. 1:5. and 1:10 v:v of DMSO). DMSO was used as negative control while Gentamicin (GM) was used as positive control. Petri dishes were incubated at $37^{\circ} \mathrm{C}$ during 18 to $24 \mathrm{~h}$ aerobically; after incubation. inhibition zone diameters were measured and documented.

\section{Preparation of sections for anatomical study}

Young sections of the plant containing stems and leaves were selected to make cross sections by hand with sharp blade and then coloring them using double coloration method [08]. Light microscope was used to check up transverse sections.

\section{RESULTS AND DISCUSSION}

\section{Chemical composition}

The hydrodistillation of the essential oil of $C$. morifolium gave a viscous liquid with a greenish color. The yield of the sample essential oil is $0.09 \%$. The essential oil tested in this study was analyzed using GC-MS to identify its major components. The retention time and chemical composition of essential oils of $C$. morifolium are presented in Table 01. The mass spectrum of C. morifolium L. essential oil is shown in Fig. 02 .

Chemical analysis led to the identification of 26 compounds representing $88.40 \%$ of the total essential oil mass. Most essential oil compounds were terpenic compounds (Fig. 03); the major compound was verbenone (2-Pinene-4-one) (17.33\%). other components present in appreciable contents were: Chrysanthenone (9.71\%). 4Epi-cubedol (07.25\%) and $\delta$-Cadinol (05.29\%).

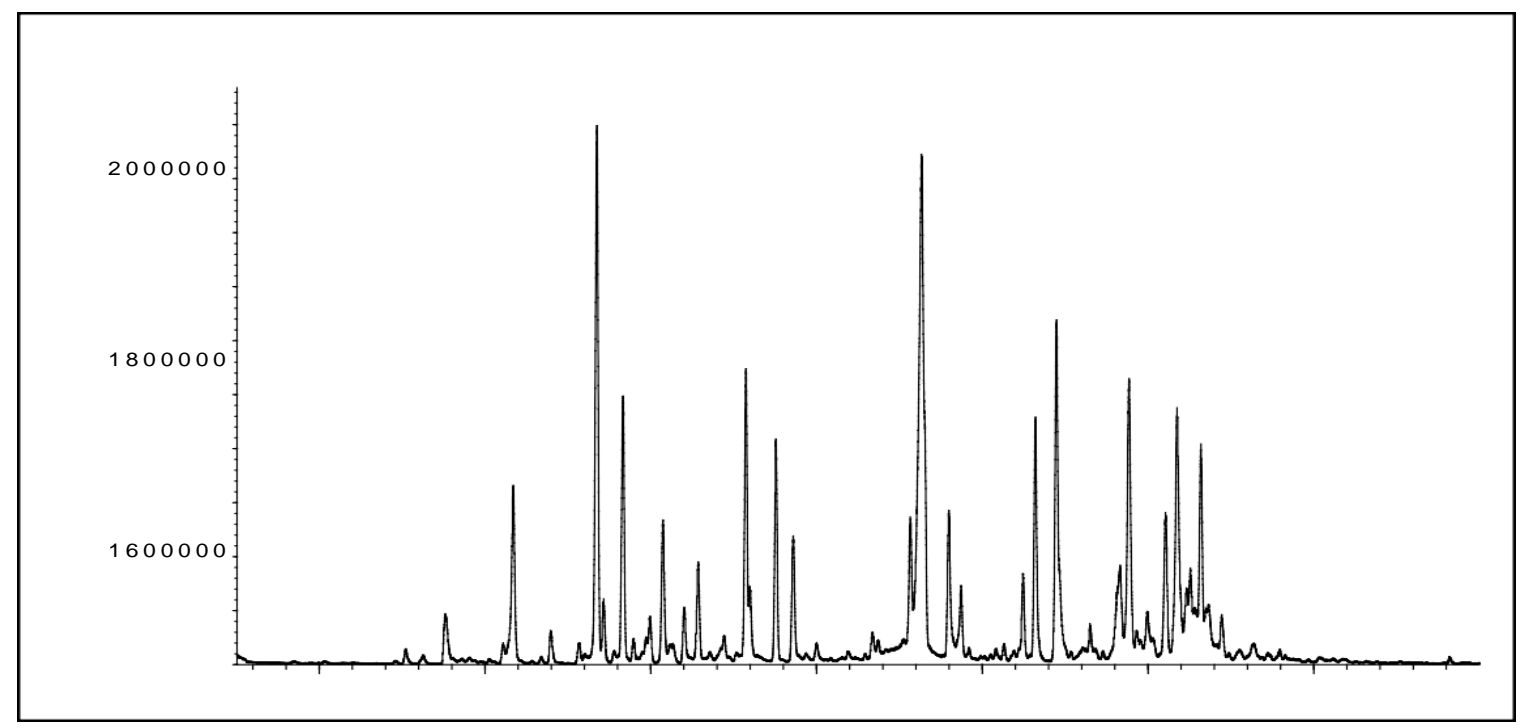

Fig. 02: Mass spectrum of $C$. morifolium L. essential oil 
Table 01: Chemical composition of the essential oil extracted from $C$. morifolium

\begin{tabular}{|c|c|c|c|c|}
\hline & RT (min) & IR & $\%$ & Compounds \\
\hline 1 & 13.808 & 974 & 1.26 & Morillo \\
\hline 2 & 15.854 & 1035 & 3.78 & Eucalyptol \\
\hline 3 & 16.989 & 1068 & 0.57 & Safranal \\
\hline 4 & 18.376 & 1106 & 9.71 & Chrysanthenone \\
\hline 5 & 18.577 & 1113 & 1.06 & 1.3-Cyclopentadiene. 5.5-dimethyl-2-ethyl- \\
\hline 6 & 19.977 & 1154 & 1.19 & Camphor \\
\hline 7 & 20.371 & 1165 & 2.28 & Verbenol (2-pine-4-ol) \\
\hline 8 & 21.014 & 1183 & 0.95 & 4-terpineol \\
\hline 9 & 21.432 & 1194 & 1.59 & Cyclohexene. 3-(3-methyl-1-butenyl) \\
\hline 10 & 22.872 & 1237 & 5.8 & Bicyclo[3.1.1]hept-2-en-4-ol. 2.6.6-trimethyl-. acetate \\
\hline 11 & 24.297 & 1279 & 2.24 & p-Mentha-1.8-dien-3-one ( limonene) \\
\hline 12 & 27.833 & 1386 & 3.3 & alfa-Copaene \\
\hline 13 & 28.171 & 1396 & 17.33 & verbenone (2-Pinene-4-one) \\
\hline 14 & 29.361 & 1435 & 1.38 & Caryophyllene \\
\hline 15 & 31.23 & 1494 & 1.6 & $\beta$-Cubebene \\
\hline 16 & 31.603 & 1507 & 4.27 & Cubedol \\
\hline 17 & 32.239 & 1529 & 7.25 & 4-Epi-cubedol \\
\hline 18 & 34.153 & 1594 & 2.86 & Nerolidol \\
\hline 19 & 34.425 & 1603 & 5.4 & Caryophylleneoxide \\
\hline 20 & 34.98 & 1623 & 1.07 & Globulol \\
\hline 21 & 35.53 & 1643 & 2.61 & $\beta$-Guaiene \\
\hline 22 & 35.878 & 1656 & 5.29 & $\delta$-Cadinol \\
\hline 23 & 36.168 & 1666 & 0.85 & 9-Isopropyl-1-methyl-2-methylene-5oxatricyclo[5.4.0.0(3.8)] undecane \\
\hline 24 & 36.282 & 1670 & 1.43 & $\alpha$-Cadinol \\
\hline 25 & 36.597 & 1681 & 2.7 & Junipercamphor \\
\hline \multirow[t]{2}{*}{26} & 37.225 & 1703 & 0.63 & Murolan-3.9(11)-diene-10-peroxy \\
\hline & & Total & 88.4 & \\
\hline
\end{tabular}

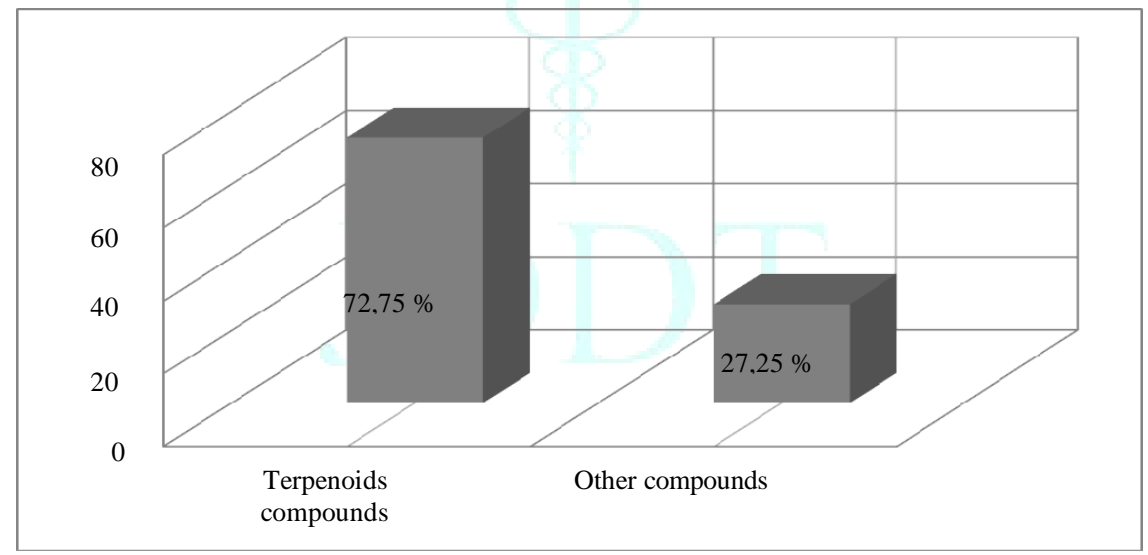

Fig. 03: the major chemical compounds of the $C$. morifolium essential oil

The results obtained in the study of Chang and Kim (2013) [09] and those obtained in the present study are similar where the yield of their sample essential oil is $0.1 \%$; whereas the yields of essential oil were $0.1 \%$ for $C$. fontanesii and $0.07 \%$ for C. coronarium[10], however the yield of essential oil of $C$. trifurcatum was $0.055 \%[11]$.

The results of present study are different from those reported in previous studies. The chemical constituents of the essential oil of Chrysanthemum morifolium Ramat from Nigeria are different, for example the compounds Verbenone. 4-epi-cubedol and $\delta$-Cadinol were absent while the main constituents were cis chrysantheny acetate (21.6\%), octadecanoic acid (19.5\%) and borneol (15.5\%)[02]; also results of Lograda et al. (2013) [10] indicate different major components in essential oil of $C$. fontanesii and $C$. coronarium from two localities in eastern Algeria (of the region Aouakas). These compounds are triene $(22.3 \%)$ and 1.1-Difluror-tetramethylcyclopropane $(11.52 \%)$ respectively; while the main components in essential oil of $C$. indicum flowers from China were 2.6.6trimethyl- bicyclo[3.1.1] hept-2-en-4-ol (21.67\%) and 2-(2.4hexa diynylidene)-1.6dioxaspiro[4.4]non-3-ene (21.41\%) [12]; another study [09] reported that major components in C. morifolium essential oils from Geonggi (Korea) were Chrysanthenyl acetate (43.74\%) and verbenol (27.85\%); whereas in another study [13] the components are Germacrene D (10.6\%). 1.8-Cineole (10.4\%) and Camphor $(10.12 \%)$ were the major constituents in $C$. indicum essential oil from the area of Mt. Mireuk in 
Korea. Previous studies confirmed that the major constituents for essential oil of Chrysanthemum species are monoterpenoids [01].

The variability of the composition of essential oils of Chrysanthemum species has been reported in several other studies, by comparing present results with it for example we observed that the components $\alpha$-Curcumene [14], Hulene- $\beta$ followed by Ledene oxide-(I) [15]; $C$ indicum :trans- Sabinol and $C$. boreale: $\beta$-Thujone[16], $C$. arcticum: Chrysanthenone (13.98\%), C. parthenium: Camphor 38.51\% [17], trans-Verbenyl acetate [03] were the dominant compounds.

The reason for these variations in essential oils composition may be attributed to factors related to ecotype, the environment including temperature, relative humidity, irradiance, photoperiod, the period of collection and the part of plant used [18] [19].

\section{Antibacterial activity}

Antibacterial activity of the essential oil was tested by the disc diffusion assay. Table 02 shows diameter of inhibition of the different concentrations of the essential oil in DMSO $(\mathrm{v} / \mathrm{v})$ against either Gram positive and negative pathogenic bacteria.
The essential oil of $C$. morifolium exhibits significant inhibitory effects toward most tested bacteria (Fig. 04); nevertheless. Pseudomonas aeruginosa ATCC 27853 and Kleibseilla pneumoniae ATCC 700603 were resistant to the essential oil. In general tested Gram negative bacteria appear more resistant than Gram positive ones. Staphylococcus aureus ATCC 25923 and Citrobacter freundi ATCC8090 were more susceptible to essential oil. The activity of $C$. morifolium essential oil against S.aureus ATCC 25923 strain is significant and expressed in varying diameters of concentration $35 \pm 1.2 \mathrm{~mm}$ in $100 \%$ concentration and $14 \pm 0.98 \mathrm{~mm}$ in $50 \%$ dilution, while the inhibition zone of Gentamicin (GM) was $26 \pm 0.23 \mathrm{~mm}$; the activity of this essential oil against $C$. freundii ATCC 8090 strain is significant and expressed in varying diameters of concentration, $21 \pm 0.87 \mathrm{~mm}$ in $100 \%$ concentration and $12 \pm 1.03 \mathrm{~mm}$ in $50 \%$ dilution, however the inhibition zone of Gentamicin (GM) was $20 \pm 0.12 \mathrm{~mm}$. Essential oil tested present moderate activity against Escherichia coli ATCC 25922 and Shigella sonnei. this activity expressed by inhibition diameters of $14 \pm 0.88 \mathrm{~mm}$ and $13 \pm 1.99 \mathrm{~mm}$ respectively in $100 \%$ dilution and $11 \pm 1.01 \mathrm{~mm}$ and $09 \pm 0.17 \mathrm{~mm}$ respectively in $50 \%$ dilution; whereas the inhibition zones of Gentamicin (GM) were $23 \pm 0.25 \mathrm{~mm}$ and $25 \pm 0.09 \mathrm{~mm}$ respectively.

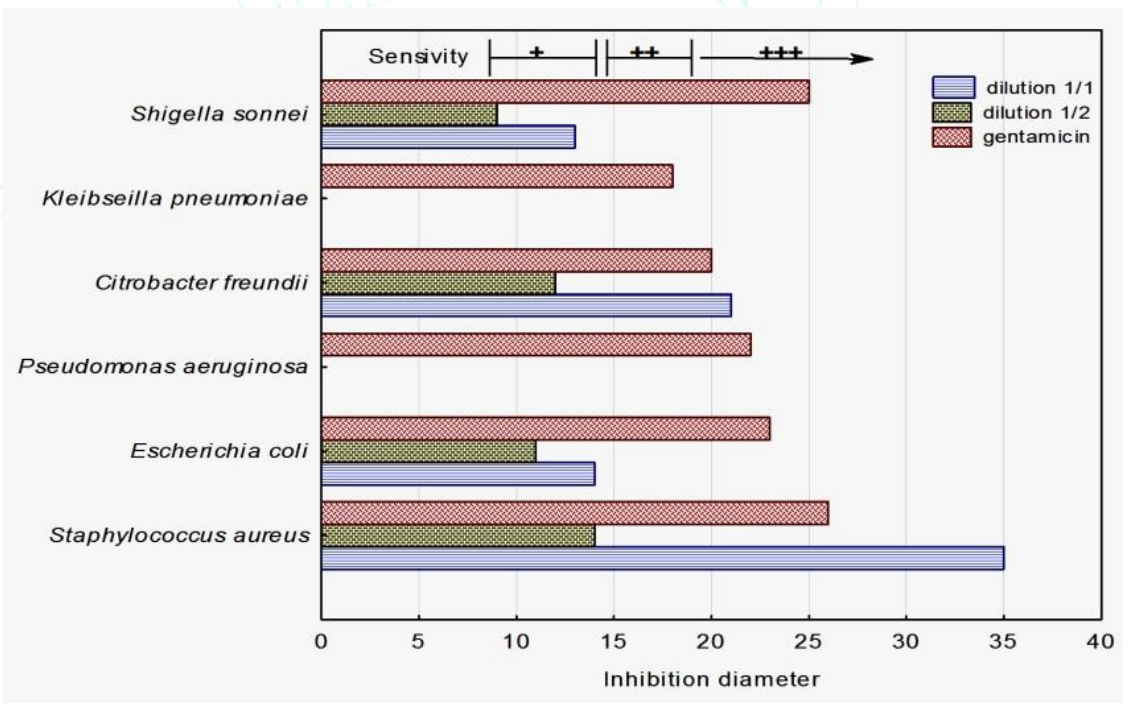

Fig 04. Antibacterial activity of $C$. morifolium essential oil

Table 02: Antibacterial activity of $C$. morifolium measured as diameter of inhibition (mm)

\begin{tabular}{|l|l|l|l|}
\hline Bacteria strains & \multicolumn{2}{|l|}{ Concentration } & \multirow{2}{*}{ Gentamicin } \\
\cline { 2 - 4 } & $\mathbf{1 0 0 \%}$ & $\mathbf{5 0 \%}$ & $26 \pm 0.23$ \\
\hline Staphylococcus aureus ATCC 25923 & $35 \pm 1.2$ & $14 \pm 0.98$ & $23 \pm 0.25$ \\
\hline Escherichia coli ATCC 25922 & $14 \pm 0.88$ & $11 \pm 1.01$ & $22 \pm 0.66$ \\
\hline Pseudomonas aeruginosa ATCC27853 & 00 & 00 & $20 \pm 0.12$ \\
\hline Citrobacter freundii ATCC8090 & $21 \pm 0.87$ & $12 \pm 1.03$ & $18 \pm 0.33$ \\
\hline Kleibseilla pneumoniae ATCC 700603 & 00 & 00 & $25 \pm 0.09$ \\
\hline Shigella sonnei & $13 \pm 1.99$ & $09 \pm 0.17$ & \\
\hline
\end{tabular}

It's noticed that Gram positive bacteria were more susceptible to essential oils than Gram negative bacteria; these results are similar to those in previews studies. This phenomenon was ascribed to possession of these bacteria to a hydrophilic polysaccharide chains as a barrier to hydrophobic essential oils [20] [21]. In previous studies the different extracts of Chrysanthemum species especially essential oils showed a significant activity against microbial activity and exhibited significant activity against both Gram positive and Gram negative bacteria [01]

The Chrysanthemum parthenium essential oil from Iran showed inhibitory effects on Escherichia coli and Salmonella typhi, but were not active against Staphylococcus aureus [22], while the essential oils of C.coronarium from Italy have no activity against Escherichia coli. Staphylococcus aureus and Pseudomonas aeruginosa [23], however the activity of $C$. coronarium 
essential oils from Houfa (Irbid governorate. Jordan) against five bacterial strains was moderate with grampositive strains and weak with gram-negative strains [24].

In other study, the antibacterial activities of essential oil of C. coronarium and $C$. fontanesii showed that the oils of both species have a very low activity) [10], in contrast the essential oil of

C. viscidehirtum exhibited significant activity against Salmonella typhi and Proteus mirabilis, also the essential oil of $C$. boreale exhibited the activity against six Gram negative bacteria and eight Gram positive bacterial strains [01]. Chrysanthemum species have pharmacological effects such as antiviral, antihypertensive, anti-bacterial and anti-inflammatory effects [25].

\section{Anatomical study}

The anatomical study that is carried out on young fresh stem of $C$. morifolium showed that Pith, xylem, phloem, cortex and epidermis are the most important tissue found (Fig 05. a. b. c) while the epidermis, mesophyll and conductive vessel are the constituent tissues of the leaf (Fig 06. a. b.c).

Observations by light microscope showed the epidermis layer of stems and leaves contained two types of hairs glandular and covering trichomes (Fig 05. d. e. f. g. h) and (Fig 06 d. e. f. g.). The protector trihomes are pluricellular (3-4 cells) having the form of the letter $\mathrm{T}$, while glandular trichomes consists of 03 cells. a base cell, cervical cell and the glandular cell in the stems (Fig 05 d.e. f. h) and without cervical cell in the leaves (Fig 06 a. b. c. d. e).

The protector and glandular trichomes were spread on the lower side of the leaves more than the upper side (Fig. $5 \mathrm{~d}$. f. g).

The results of present study are similar (protector trihomes pluricellular having the form of the letter T) with those obtained by [26] [27] and [28]. Several studies confirm that climatic and environmental conditions play an important role in the growth and shape of plants.

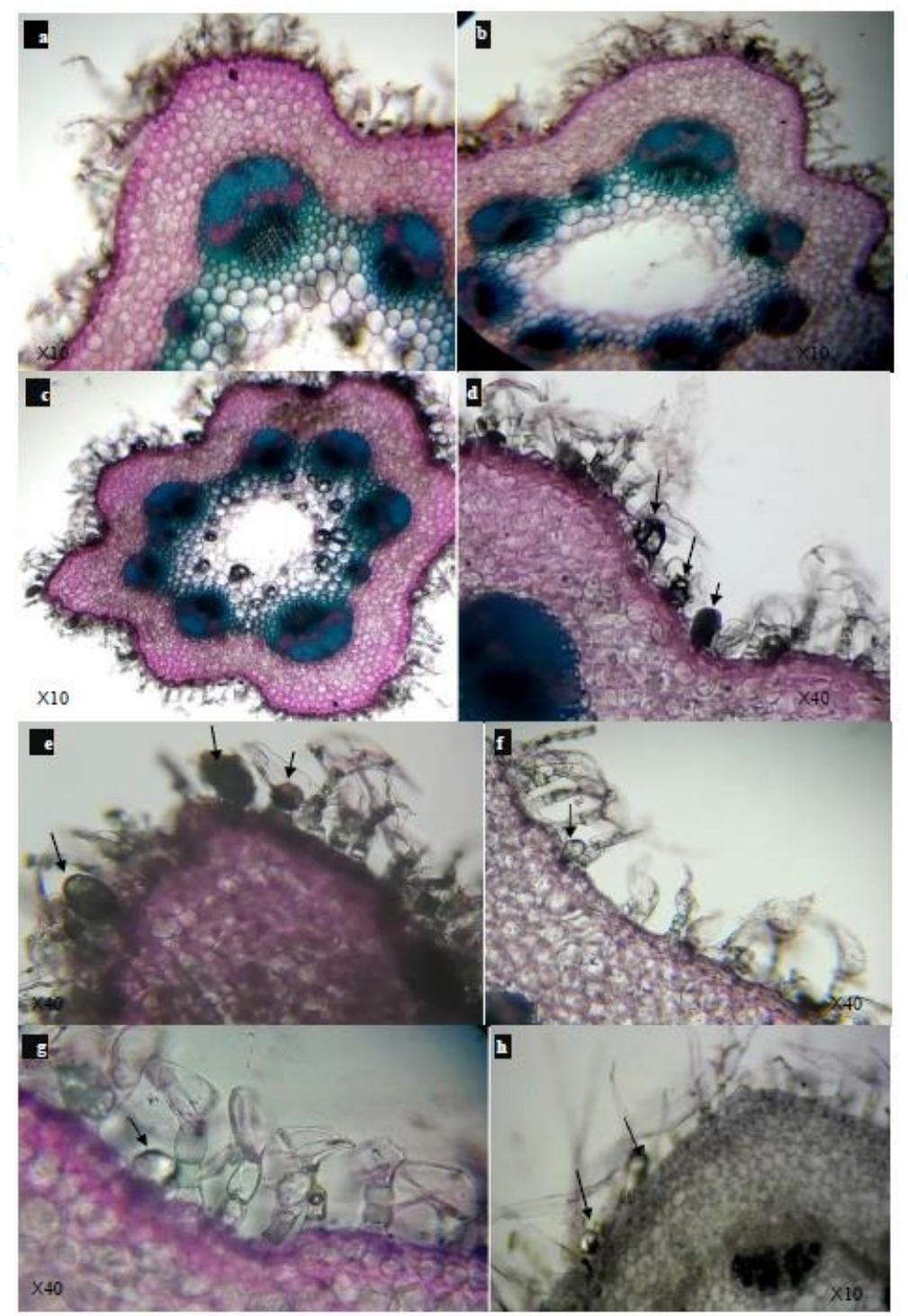

Fig 05: Cross section of $C$. morifolium (stem)

(a.b.c) Cross section in stem showing différent tissue. (d.e.f.g.h) Cross section in stem showing covering and glandular trichomes 


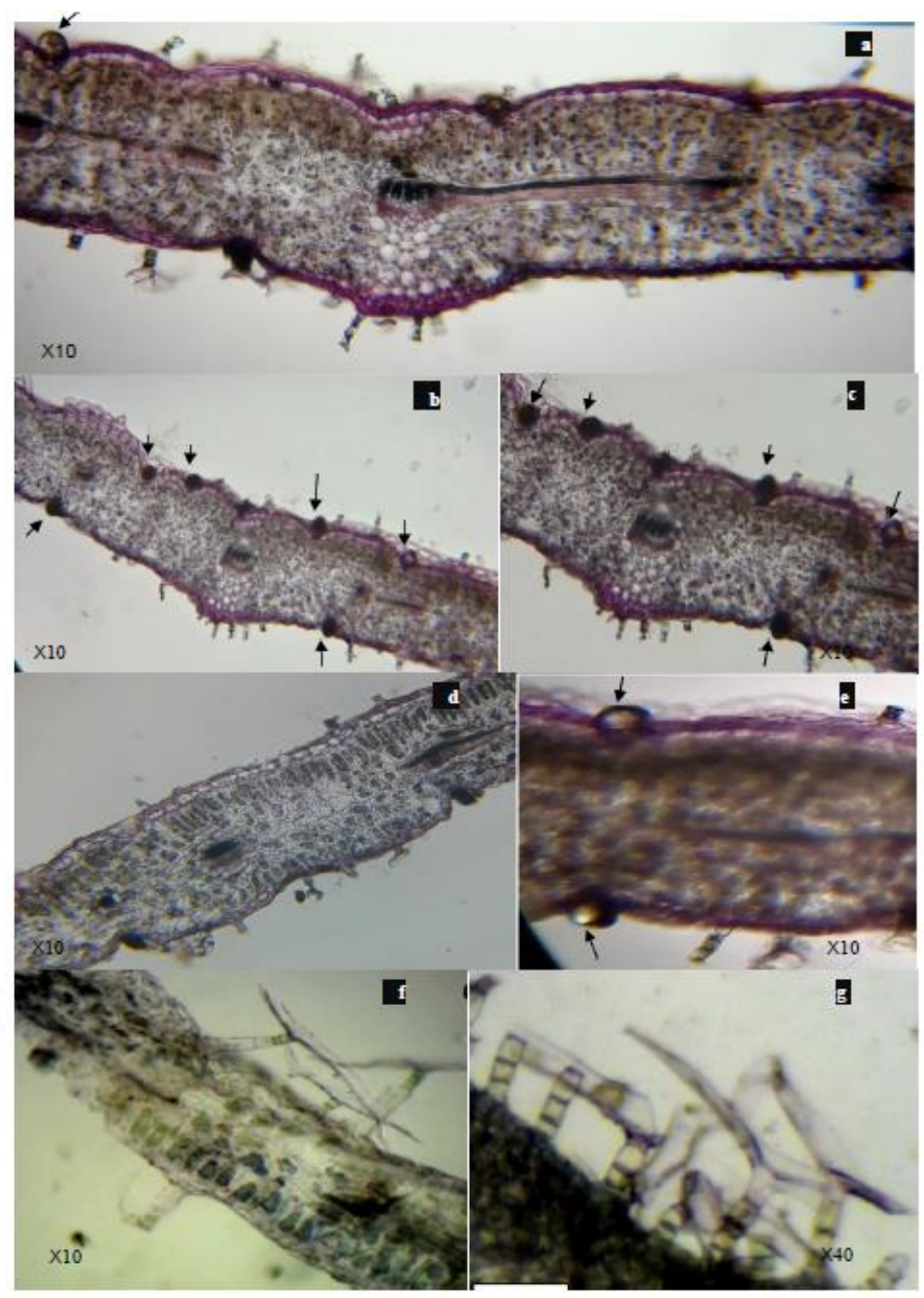

Fig 06: Cross section of $C$. morifolium (leaf)

(a) Cross section in leaf showing différent tissue, (b. c. d) Cross section in leaf showing larger vascular bundle, (e) glandular trichomes, (f. g) protector trichomes

\section{CONCLUSION}

The chemical composition of the essential oil of Chrysanthemum morifolium aerial parts is characterized by the presence of verbenone (2-Pinene-4-one, followed by Chrysanthenone, 4-Epi- cubedol and $\delta$-Cadinol as dominant components. this chemical composition is differs comparatively from the oil composition given in previous studies.

Essential oil of $C$. morifolium present significant antibacterial activity, also it is noted that the effect of this essential oil on positive bacteria is greater than negative bacteria. The antibacterial activity of $C$. morifolium essential oil on positive bacteria strains was exceeded those obtained with antibiotic.

The anatomical study which was performed on young fresh stems showed the presence of two types of trichomes: protector trichomes (pluricellular (3-4 cells) having the form of the letter $\mathrm{T}$ ) and secretor trichomes (small and simple). C. morifolium is rich in secretor glands and therefore rich in essential oils; these trichomes has an important role to identified this vegetal species

\section{REFERENCES}

[01] Kumar A.. Singh S.P. and Bhakuni R. S. secondary metaboliteof chrysanthemum genusand their biological activities. Current science; Vol 2005; 89(10):1489-1501.

[02] Oladipupo A. Lawal. Isiaka A. Ogunwande. Olusola F. Olorunloba and Andy R. Opoku. The essential oils of Chrysanthemum morifolium Ramat.from Nigeria. American Journal of Essential Oils and Natural Products; 2014; 2(1):63-66.

[03] Ah-Reum Han, Bomi Nam, Bo-Ram Kim, Ki-Chang Lee, BeomSeok Song, Sang Hoon Kim, Jin-Baek Kim, and Chang Hyun Jin. Phytochemical Composition and Antioxidant Activities of Two Different Color Chrysanthemum Flower Teas. Molecules. 2019; 24:329.

[04] Quezel P. et Santa S. Nouvelle flore de l'Algérie et des régions désertiques et méridionales. Tome 2. Centre National de la Recherche Scientifique. Paris. 1963.

[05] El Kolli H., Laouer H. and El Kolli M. Chemical composition and biological activities of the essential oils and the methanolic extracts of Bunium incrassatum and Bunium alpinum from ALGERIA. J. Chil. Chem. Soc., 2017; 62(1):3335-3341.

[06] Koldas S., Demirtas I., Ozen T., Demirci M. A. and Behçet L. Phytochemical screening, anticancer and antioxidant activities of Origanum vulgare L. ssp. viride (Boiss.) Hayek, a plant of traditional usage. J Sci Food Agric; 2014; 95:786-798. 
[07]Rahal K. Standardization of Antimicrobial Susceptibility in Human Medicine at the National Scale According to WHO Recommendations. 4th ed. Geneva: Ministry of Health, Population and Hospital Reform. 2005.

[08] Locquin et Langeron, Manuel de microscopie. Masson. Paris. 1978, pp: 352.

[09] Chang Kyung-Mi and Kim Gun-Hee. Volatile Aroma Constituents of Gukhwa (Chrysanthemum morifolium R.). Food Sci. Biotechnol. 2013; 22(3):659-663.

[10] Lograda T.. Ramdani M.. Chalard P.. Figueredo G.. Silini H. and Kenoufi M. Chemical composition. antibacterial activity and chromosome number of Algerian populations of two chrysanthemum species. Journal of Applied Pharmaceutical Science 2013; 3(8 Suppl 1):S6-S11.

[11] Ben Sassi A.. Harzallah-Skhiri F.. Chraief I.. Bourgougnon N.. Hammami M.. Aouni M. Chemical composition and antimicrobial activities of the essential oil of (Tunisian) Chrysanthemum trifurcatum (Desf.) Batt. and Trab. Flowerheads. C. R. Chimie. 2008; 11:324-330.

[12] Wu L.-Y.. Gao H.-Z.. Wang X.-L.. Ye J.-H.. Lu J.-L. and Liang Y. R. Analysis of chemical composition of Chrysanthemum indicum flowers by GC/MS and HPLC. Journal of Medicinal Plants Research. 2010; 4(5):421-426.

[13] Jung E.-K. Chemical Composition and Antimicrobial Activity of the Essential Oil of Chrysanthemum indicum Against Oral Bacteria. Journal of Bacteriology and Virology. 2009; 39(2):6169.

[14] Kuang C. l.. Lv D.. Shen G.h.. Li S. s.. Luo Q. y.. Zhang Z.q Chemical composition and antimicrobial activities of volatile oil extracted from Chrysanthemum morifolium Ramat.Journal of Food Science and Technology; New Delhi. 2018; 55. № 7. 2786-2794. DOI:10.1007/s13197-018-253 3203-1.

[15] Sun Q. Hua S. Ye J. Zheng X and Liang Y. Flavonoids and volatiles in Chrysanthemum morifolium Ramat flower from Tongxiang County in China. African Journal of Biotechnology. 2010; 9256 (25). pp.3817-3821.

[16] Hwang K. H.. Kim D. H.. Park J. S.. Kang K.. Yun K. W. Identification of volatile components of four Chrysanthemum taxa (Asteraceae) using headspaceGC/MS. International Journal of Applied Research in Natural Products. 2016; 9(3):26-30.

[17] Grzeszczuk M.. Wesołowska A. Composition of essential oils and some antioxidants in flowers of three Chrysanthemum cultivars. Journal of Elementology. 2017; 23(4):1331-1342.

[18] Chauhan R.S.. Kaul M.K.. Shahi A.K.. Kumar Arun. Ram G.. Tawa A. Chemical composition of essential oils in Mentha spicata L. accession [IIIM(J)26] from North-West Himalayan region. India. Industrial crops and products; 2009; 29:654-656.

[19] Lamendin H.. Toscano G.. Rquirand P. Phytothérapie et aromathérapie buccodentaires. EMC-Dentisterie; 2004 ; 1:179_ 192.

[20] Inouye S.. Uchida K.. Yamaguchi H. In-vitro and in-vivo antiTrichophyton activity of essential oils by vapour contac. Mycoses. 2001; 44:99-107.

[21] Burt S. Essential oils: their antibacterial properties and potential application in foods-a review. International journal of food microbiology. 2004; 94:223-253.

[22] Shafaghat A.. Larijani K. and Salimi F. Composition and Antibacterial Activity of the Essential Oil of Chrysanthemum parthenium Flower from Iran. Jeobp 2010; 12(6):708-713.

[23] Senatore F., Rigano D., De Fusco R. and Bruno M. Composition of the essential oil fromflower heads of Chrysanthemum coronium L. (Asteraceae) growing wild in Southern Italy. Flavour and Fragrace Journal. 2004; 19(2):149152.

[24] Bardaweel K. S.. M. Hudaib M.. A. Tawaha K.. and M. Bashatwah R. Studies on the In Vitro Antiproliferative. Antimicrobial. Antioxidant. and Acetylcholinesterase Inhibition Activities Associated with Chrysanthemum coronarium Essential Oil. Evidence-Based Complementary and Alternative Medicine. Volume 2015. Article ID 790838. pp1-6.

[25] Wang J.. Chen D.. Liang L. Chemical constituents from flowers of Chrysanthemum indicum. China Journal of Chinese Materia Medica. 2010; 35(6):718-721.

[26] Mircea C. C.. Cioanca O.. Draghia L.. Hancianu M. Morphological Characteristics. Phenolic and Terpenoid Profiles in Garden Chrysanthemum Grown in Different Nutritional Conditions. Not Bot Horti Agrobo. 2015; 43(2):371-379.

[27] Lv G.. Tang D... Chen F. Sun Y.. Fang W.. Z. Guan. Liu Z.. Chen S. The anatomy and physiology of spray cut chrysanthemum pedicels. and expression of a caffeic acid 3-0methyltransferase homologue. Postharvest Biology and Technology 2011; 60:244-250.

[28] POPA F. and ŞIPOŞ M. Epidermal Formation - Trichomes. Biharean Biologist. 2009; 3.289(1):27-32. 